\title{
Exposure to Electromagnetic Fields (EMF) from Submarine Power Cables Can Trigger Strength-Dependent Behavioural and Physiological Responses in Edible Crab, Cancer pagurus (L.)
}

\author{
Kevin Scott ${ }^{1, *}$, Petra Harsanyi ${ }^{1,2,3}$, Blair A. A. Easton ${ }^{1}$, Althea J. R. Piper ${ }^{1}$, Corentine M. V. Rochas ${ }^{1}$ \\ and Alastair R. Lyndon ${ }^{2}$ \\ 1 St Abbs Marine Station, The Harbour, St Abbs TD14 5PW, UK; petra.harsanyi@marinestation.co.uk (P.H.); \\ blair.easton@marinestation.co.uk (B.A.A.E.); alfie.piper@marinestation.co.uk (A.J.R.P.); \\ corentine.rochas@marinestation.co.uk (C.M.V.R.) \\ 2 School of Energy, Geoscience, Infrastructure and Society, Heriot-Watt University, Edinburgh EH14 4AS, UK; \\ a.r.lyndon@hw.ac.uk \\ 3 Institute of Biology, Eötvös Loránd University, H-1053 Budapest, Hungary \\ * Correspondence: kevin.scott@marinestation.co.uk
}

check for updates

Citation: Scott, K.; Harsanyi, P.; Easton, B.A.A.; Piper, A.J.R.; Rochas, C.M.V.; Lyndon, A.R. Exposure to Electromagnetic Fields (EMF) from Submarine Power Cables Can Trigger Strength-Dependent Behavioural and Physiological Responses in Edible Crab, Cancer pagurus (L.). J. Mar. Sci. Eng. 2021, 9, 776. https://doi.org/ $10.3390 /$ jmse 9070776

Academic Editor: Ka-Hou Chu

Received: 21 June 2021

Accepted: 15 July 2021

Published: 17 July 2021

Publisher's Note: MDPI stays neutral with regard to jurisdictional claims in published maps and institutional affiliations.

Copyright: (c) 2021 by the authors. Licensee MDPI, Basel, Switzerland. This article is an open access article distributed under the terms and conditions of the Creative Commons Attribution (CC BY) license (https:// creativecommons.org/licenses/by/ $4.0 /)$.

\begin{abstract}
The current study investigated the effects of different strength Electromagnetic Field (EMF) exposure $(250 \mu \mathrm{T}, 500 \mu \mathrm{T}, 1000 \mu \mathrm{T})$ on the commercially important decapod, edible crab (Cancer pagurus, Linnaeus, 1758). Stress related parameters were measured (L-Lactate, D-Glucose, Total Haemocyte Count (THC)) in addition to behavioural and response parameters (shelter preference and time spent resting/roaming) over $24 \mathrm{~h}$ periods. EMF strengths of $250 \mu \mathrm{T}$ were found to have limited physiological and behavioural impacts. Exposure to $500 \mu \mathrm{T}$ and $1000 \mu \mathrm{T}$ were found to disrupt the L-Lactate and D-Glucose circadian rhythm and alter THC. Crabs showed a clear attraction to EMF exposed (500 $\mu \mathrm{T}$ and $1000 \mu \mathrm{T})$ shelters with a significant reduction in time spent roaming. Consequently, EMF emitted from MREDs will likely affect crabs in a strength-dependent manner thus highlighting the need for reliable in-situ measurements. This information is essential for policy making, environmental assessments, and in understanding the impacts of increased anthropogenic EMF on marine organisms.
\end{abstract}

Keywords: Cancer pagurus; edible crab; electromagnetic field; haemolymph parameters; circadian rhythm; L-Lactate; D-Glucose; windfarm; environmental stressor

\section{Introduction}

Anthropogenically induced climate change through the burning of fossil fuels has a significant evidence base, which has led to many governments initiating programs for increased production of renewable or 'green' energy [1]. Marine Renewable Energy (MRE) promises to assist by providing clean, inexhaustible energy and aid in the reduction of Greenhouse Gas (GHG) emissions [2]. It is expected that, with the current implications of climate change, the number of Marine Renewable Energy Devices (MREDs) will increase, especially for locations that have wind and wave resources [1,3]. The increase in offshore renewables in Europe is expected to contribute to $10 \%$ of the continent's energy requirements by $2030[4,5]$, with a current rise in installed wind power capacity from 0.7 GigaWatts (GW) in 2005 to 22 GW in 2019 [6,7]. Currently, the UK, which has the largest offshore windfarm in the world, has more projects in planning and construction than any other country [8].

There are both social and environmental concerns with the development of MREDs including habitat loss, perceived aesthetic problems, collision risks, increased anthropogenic noise, and exposure to increased electromagnetic fields (EMF) [1,9-13]. The continued assessment of the implications of these structures is essential in contributing to the existing knowledge gaps surrounding the potential impacts of MREDs in the marine environment. 
The number of subsea power cables connecting turbines, storage banks and export cables to shore will subsequently rise with the increase in deployments. These cables generate both an electric field (E-field) and a magnetic field (B-field) [10]. Through industry standard insulation, E-fields can be successfully contained within the cable with no leakage, however, there is no industry standard insulation that is able to prevent B-field leakage [10]. The leaked B-field interacts with surrounding cables emissions, due to common cable configurations, leading to the creation of an induced electromagnetic field (iE-field) which is subsequently influenced by saltwater ions moving via underwater currents i.e., Lorentz force [14].

There is a great variation in the EMF arising from different deployments which are the result of different currents (alternating (AC), or direct (DC)), cable length, distance from conductors, and energy output from the turbines [15]. Despite the large variations in strength, it is agreed that the highest strengths are likely to be found around the cables compared to turbine bases, particularly export cables [16]. EMF strengths predicted around subsea power cables, as reported in the literature, vary from 140-8000 $\mu \mathrm{T}[15,17,18]$. A commonly utilised cable operating at $1600 \mathrm{~A}$ is expected to produce an EMF of $3200 \mu \mathrm{T}$ in a perfect wire, at the cable surface [17]. As with all EMF, the values will decrease with distance from the source, resulting in a field strength of $320 \mu \mathrm{T}$ and $110 \mu \mathrm{T}$ at $1 \mathrm{~m}$ and $4 \mathrm{~m}$ respectively [17]. EMF values used previously in similar scientific studies range from 65-165 mT [13,18-22].

The edible crab, Cancer pagurus, is a commercially important decapod found throughout western Europe from Norway to Portugal, from the intertidal to depths of around $400 \mathrm{~m}$ [23]. C. pagurus are heavily exploited throughout their geographic range and are the second most important shellfish fishery in the UK [24]. Studies have shown that, given the life cycle and behavioural patterns of this species, they are highly likely to experience subsea power cables, either by attraction to EMF [13] or by the creation of scour protection zones around turbine bases, which may subsequently act as artificial reefs [25-29]. The sensory mechanisms involved in magneto-detection in C. pagurus is unknown, however, the leading theory behind EMF detection in crustaceans is magnetite magnetoreception. Magnetite $\left(\mathrm{Fe}_{3} \mathrm{O}_{4}\right)$, a mineral found in the tissues of many organisms including crustaceans [30,31], reorientates during exposure to magnetic fields which subsequently acts upon secondary sensors $[32,33]$. A study conducted on Caribbean spiny lobsters, Palinurus argus, found changes in orientation after exposure to magnetic pulses [31,34]. Previous studies on C. pagurus have concluded that exposure to EMF, at strengths of $2.8 \mathrm{mT}$ and $40 \mathrm{mT}$, elicits both behavioural and physiological changes in commonly used stress parameters [13]. In crustaceans, analysis of haemolymph enables the detection of abnormalities in internal chemical processes caused by increased stress, allowing accurate assessment of stress response via L-Lactate, D-Glucose, and THC [35-38]. Behavioural and response parameters (shelter preference, time spent roaming/resting) have been shown to be reliable indicators of stress, particularly in relation to EMF exposure [13].

The high variability in EMF strengths predicted around cables and those applied in scientific research, combined with no standardisation across studies and a lack of in-situ measurements makes the topic of EMF research problematic. As a result of these limitations, along with a lack of knowledge on detection limits within these species, there is a need to utilise a variety of strengths to begin the practice of using 'dose-response' studies to enhance reliability.

The aims of the current study are to build upon previous work undertaken to further assess the impacts of multiple EMF strengths, via previously confirmed stress parameters, on C. pagurus [13].

\section{Materials and Methods}

Intermoult crabs were collected from Berwickshire Marine Reserve (St Abbs, Berwickshire, UK) by local fishermen for experimentation. Crabs were kept in $1000 \mathrm{~L}$ flow through tanks with ambient sea temperature and a natural photoperiod for a minimum acclima- 
tion period of 1 week at densities of no greater than 5 crabs per tank. Crabs were sexed, weighed $(\mathrm{g})$, carapace width measured $(\mathrm{mm})$, and assigned a condition to ensure only intact, healthy crabs assigned a value of 1 and 2 were utilized [13]. Only crabs that were at minimum landing size $(\geq 150 \mathrm{~mm})$ were used during experimentation. Experimentation was conducted between May-June 2019.

\subsection{Physiological Analysis}

\subsubsection{Helmholtz Coils}

Two Helmholtz coils were utilised throughout the experiment with one set to produce a homogeneous EMF of the required strengths and the second remaining unpowered to act as a control. Building upon previous research conducted where $2.8 \mathrm{mT}$ and $40 \mathrm{mT}$ were utilised, strengths of $250 \mu \mathrm{T}, 500 \mu \mathrm{T}$, and $1000 \mu \mathrm{T}$ were utilised to represent the lower values predicted in specific models $[13,15,39,40]$. Each Helmholtz coil was mapped using a gaussmeter (AlphaLab, Inc, Salt Lake City, Utah, USA, Gaussmeter Model GM-2) prior to experimentation.

Within each Helmholtz coil, six 30 L glass tanks were set up within 60 L black ABS water baths to ensure temperature stability and reduce visual stimuli of other crabs in the neighbouring tanks. Each tank contained an individual air stone, received a constant supply of temperature controlled (TECO TK2000) flow through seawater (ultraviolet (UV) sterilised and filtered). Temperature and dissolved oxygen were constantly measured via data loggers (Onset HOBO temperature pendant) and a multiprobe (YSI ProDSS) and kept constant at $13 \pm 0.2{ }^{\circ} \mathrm{C}$ and $>98 \%$ respectively.

\subsubsection{Haemolymph Analysis}

Individual crabs were placed into the tanks in the Helmholtz coils and allowed to acclimate for a period of $24 \mathrm{~h}$ before one coil was switched on. To obtain baseline data, haemolymph was collected before exposure ( 0 h-09:00 a.m.) then again after $4 \mathrm{~h}(13: 00$ p.m.), 8 h (17:00 p.m.) and 24 h (09:00 a.m.). All haemolymph collection was staggered with $5 \mathrm{~min}$ between each sample to ensure time consistency throughout the experiment. Haemolymph samples were collected, within $60 \mathrm{~s}$, from the arthrodial membrane at the base of the fifth walking leg using sterile $1 \mathrm{~mL}$ pre-chilled syringes with 25-gauge $(\mathrm{G})$ needles. A total of $800 \mu \mathrm{L}$ was collected from each crab and immediately transferred to a $1.5 \mathrm{~mL}$ cryogenic vial and frozen in liquid nitrogen. Samples were then stored in a freezer $\left(-25^{\circ} \mathrm{C}\right)$ until use. A total of 20 crabs were analysed at each field strength with 10 acting as control and 10 exposed to EMF. Due to the lack of clarity concerning the potential carryover effects of EMF exposure, combined with animal behavioural habituation, separate individuals were used as control groups and EMF exposed groups with no individuals reused throughout the experiment.

Haemolymph was deproteinated based on the procedure by Paterson and Spanoghe [35]. Samples were mixed with an equal volume of chilled $0.6 \mathrm{M}$ perchloric acid (BDH 10175). Denatured proteins were separated by centrifugation at 25,000 $\times g$ for $10 \mathrm{~min}$ (Eppendorf $5417 \mathrm{C}$, rotor $30 \times 1.5-2 \mathrm{~mL}$ ). The supernatant was mixed with $3 \mathrm{M}$ potassium hydroxide (BDH 29628) and centrifuged at $25,000 \times g$ for a further $10 \mathrm{~min}$ to remove precipitation. The samples were then frozen and stored at $-25^{\circ} \mathrm{C}$.

\section{D-Glucose}

D-Glucose concentration was determined using the D-Glucose assay kit (GAGO201KT) [38]. The stored haemolymph was thawed before analysis, $150 \mu \mathrm{L}$ of the sample was mixed with $300 \mu \mathrm{L}$ of reagent assay and incubated for $30 \mathrm{~min}$ at $37^{\circ} \mathrm{C}$ in a water bath. The reaction was stopped using $300 \mu \mathrm{L}$ of $12 \mathrm{~N}$ sulphuric acid (BDH). Absorbance was then measured in parallel measurements in microcuvettes at $540 \mathrm{~nm}$. D-Glucose concentrations were then calculated using a calibration curve of standards with a known concentration. 


\section{L-Lactate}

Deproteinated haemolymph samples were analysed for L-Lactate concentration using a colorimetric L-Lactate assay kit (Abcam ab65331). $50 \mu \mathrm{L}$ of reaction mix (L-Lactate assay buffer $(46 \mu \mathrm{L})$, L-Lactate substrate mix $(2 \mu \mathrm{L})$ and L-Lactate enzyme mix $(2 \mu \mathrm{L}))$, were added to a $50 \mu \mathrm{L}$ deproteinated haemolymph sample. The reaction mix and sample mix were then incubated at room temperature for $30 \mathrm{~min}$ then spectrophotometrically analysed in parallel measurements at $450 \mathrm{~nm}$. Concentrations were determined using a curve of values produced by spectrophotometrically assessing calibration standards of known concentrations.

\section{Total Haemocyte Count}

Fifty microliters of haemolymph were added to $150 \mu \mathrm{L}$ cooled $5 \%(v / v)$ formaldehyde (Brunel Microscope Ltd. Chippenham, UK) prior to the remaining haemolymph sample being frozen in liquid nitrogen. Haemolymph samples were dispensed to centrifuge tubes, mixed thoroughly, and kept on ice to prevent coagulation. Total Haemocyte Count (THC) of individual crabs were estimated with a Neubauer haemocytometer under magnification $(\times 100)$ with a Leica (MC170 HD) compound microscope. For accuracy, 9 images were taken of the haemocytometer and 3 images were chosen at random for analysis. THC was expressed as the number of cells in $1 \mathrm{~mL}$ of haemolymph.

\subsection{Behavioural Analysis \\ Shelter Selection}

A total of eight $70 \mathrm{~L}$ experimental tanks were set up for each type of shelter selection trial (single or dual). One (single shelter trials) or two (dual shelter trials) black ABS shelters (300 $\mathrm{mm} \times 200 \mathrm{~mm} \times 100 \mathrm{~mm}$ ) were constructed and secured to the bottom of the tanks, with 4 solenoid electromagnets under each shelter (Figure 1). Partition screens around the experimental area and opaque tanks were used to reduce visual stimuli.
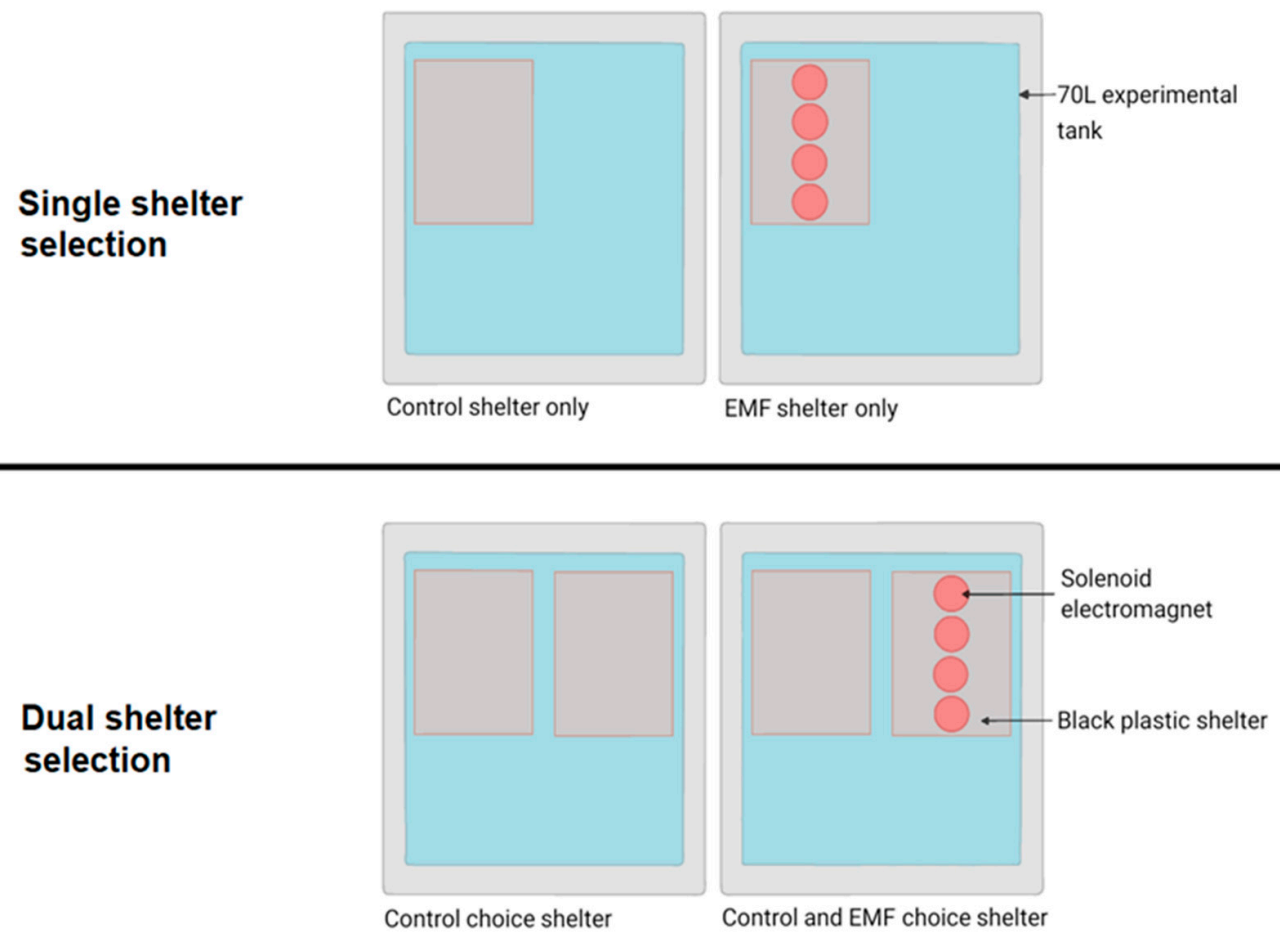

Figure 1. The four shelter experimental designs showing single shelter selection (top) and dual choice shelter selection (bottom) layouts. EMF (right, magnets powered) and corresponding controls (left, magnets unpowered). 
During single and dual shelter trials, the electromagnets were powered under 4 of the tanks with the remaining 4 unpowered acting as a control (Figure 1). Control tanks were randomised to reduce bias. The EMF was mapped for each tank using a gaussmeter (AlphaLab, Inc Gaussmeter Model GM-2) to ensure the correct field strength was obtained $(250 \mu \mathrm{T}, 500 \mu \mathrm{T}, 1000 \mu \mathrm{T})$.

An individual crab was placed into the centre of each tank and allowed to acclimate for a period of $24 \mathrm{~h}$ with the acclimation period being recorded. InfraRed cameras (Sannce 1080p IR surveillance DVR system) were suspended above all tanks and set to automatically record for $24 \mathrm{~h}$ acclimation and $24 \mathrm{~h}$ experimentation to ensure crab location could be determined. The video files were then analysed from 23:00 p.m.-06:00 a.m., the period during which this species is most active, using Solomon Coder (beta version 17.03.22) to determine the percentage of time spent in the shelters or free roaming within the tank. Time spent within the shelters or free roaming within the tank was calculated as a percentage of the total trial time (420 $\mathrm{min})$ [41].

\subsection{Statistical Analysis}

Results were expressed as mean \pm standard error (SEM). Data were assessed for normality using the Shapiro-Wilk test for normality and Levene's test for equality of error variances. When data met these assumptions, repeated measures multivariate analysis of variance (MANOVA) followed by posthoc analysis by Tukey's test was used. Differences between the treatments were tested by Student's $t$-test and paired samples $t$-test as appropriate. If data did not meet parametric assumptions, Mann-Whitney U-test and Wilcoxon matched pairs signed rank tests were used. All statistics were tested at a probability of 0.05 (IBM SPSS Statistics v.23 SPSS Corp. Chicago, IL, USA).

\section{Results}

\subsection{Physiological Analysis}

3.1.1. Haemolymph Analysis

\section{D-Glucose}

Significant differences in D-Glucose concentration were observed between sampling times and between treatments $(\mathrm{F}(3,316)=17.51, p<0.001, \mathrm{~F}(3,316)=4.12 p<0.05$, repeated measures MANOVA). D-Glucose levels followed a similar circadian rhythm in control and EMF exposed crabs, with significant increases towards peak locomotor activity $(\mathrm{F}(3,316)=59.98, p<0.05$, repeated measures ANOVA). D-Glucose concentrations showed significant increases between $0 \mathrm{~h}$ and $4 \mathrm{~h}$ and $0 \mathrm{~h}$ and $8 \mathrm{~h}$ in control conditions and during exposure to all three EMF strengths ( $p<0.05$, posthoc Tukey's test) (Figure 2). D-Glucose concentrations had returned to initial levels after $24 \mathrm{~h}$ in all samples, resulting in no significant difference from $0 \mathrm{~h}$. There were no significant differences in D-Glucose concentration between control and $250 \mu \mathrm{T}$ EMF exposed crabs at any sampling point (control $0.46 \pm 0.03 \mathrm{mM}, 250 \mu \mathrm{T} 0.45 \pm 0.05 \mathrm{mM}$ ). Crabs exposed to $500 \mu \mathrm{T}$ and $1000 \mu \mathrm{T}$ EMF showed significantly higher after D-Glucose concentrations at $4 \mathrm{~h}(0.91 \pm 0.11 \mathrm{mM}$, $1.06 \pm 0.11 \mathrm{mM}$ respectively) and $8 \mathrm{~h}(0.89 \pm 0.11 \mathrm{mM}, 0.97 \pm 0.11 \mathrm{mM}$ respectively) exposure compared to the control group $(0.65 \pm 0.08 \mathrm{mM}, 0.55 \pm 0.07 \mathrm{mM}),(p<0.05$, posthoc Tukey's test). Haemolymph D-Glucose concentrations after $24 \mathrm{~h}$ exposure to $500 \mu \mathrm{T}$ and $1000 \mu \mathrm{T}$ EMF returned to baseline levels and did not differ significantly from the control value at $24 \mathrm{~h}$. 


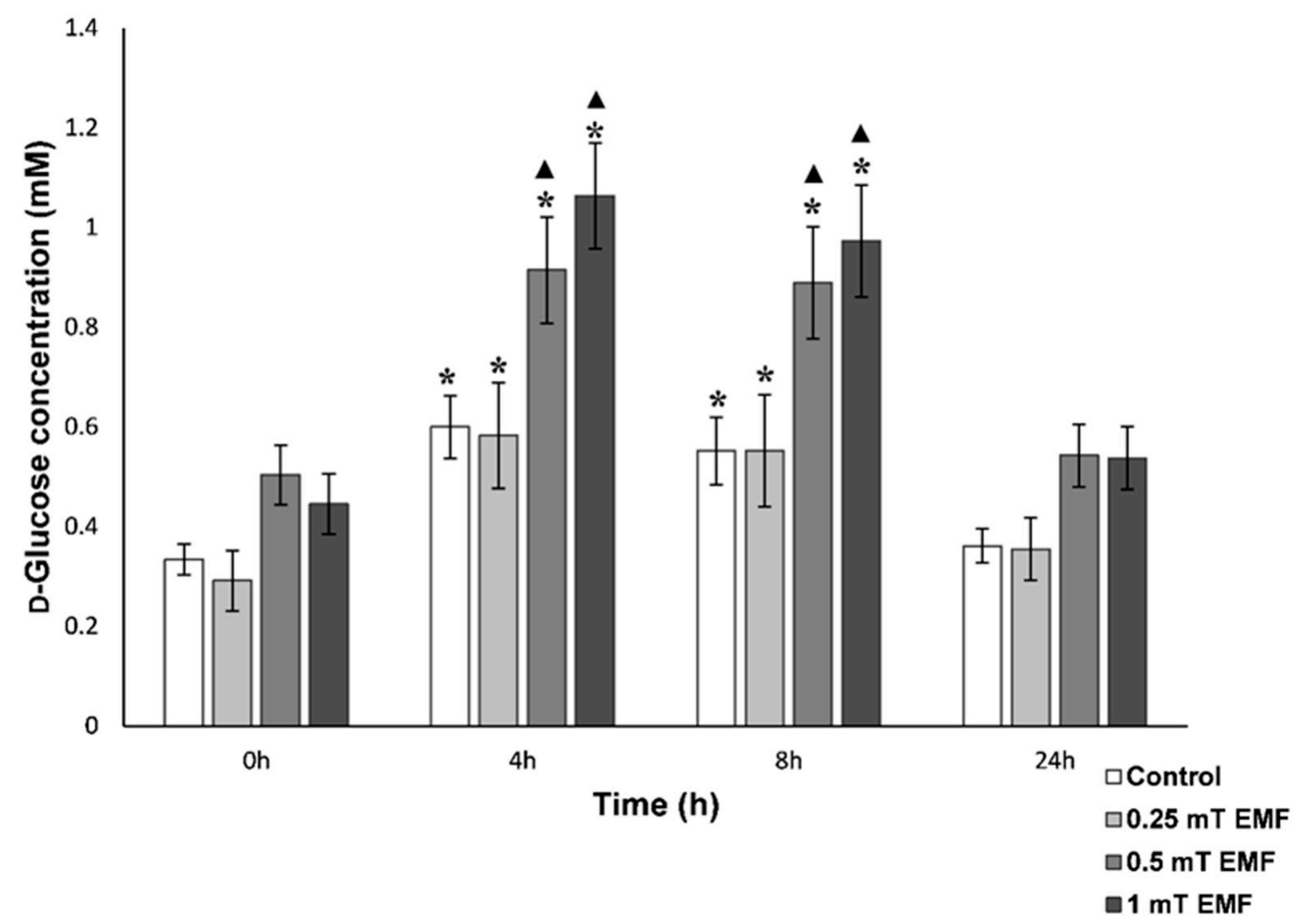

Figure 2. D-Glucose concentration over a $24 \mathrm{~h}$ period in control conditions and exposure to EMF at $250 \mu \mathrm{T}, 500 \mu \mathrm{T}, 1000 \mu \mathrm{T}$ strength. Sample times consisted of $0 \mathrm{~h}$ (09:00 a.m.), 4 h (13:00 p.m.), 8 h (17:00 p.m.), 24 h (09:00 a.m.). Values are presented as mean $\pm \mathrm{SEM},{ }^{*}$ is the significance from the $0 \mathrm{~h}$ within respective treatments, $\boldsymbol{\Delta}$ is the significance from the control group for each treatment at respective sampling times $\left({ }^{*}, p<0.05\right),(\boldsymbol{\Lambda}, p<0.05) . \mathrm{N}=10$ individuals for control and $\mathrm{N}=10$ individuals for EMF per treatment, total samples of $\mathrm{N}=40$ control, $\mathrm{N}=40 \mathrm{EMF}$.

\section{L-Lactate}

L-Lactate followed a circadian rhythm with increased concentrations coinciding with periods of high activity in control conditions and during exposure to $250 \mu \mathrm{T}$ EMF ( $8 \mathrm{~h}$, $0.63 \pm 0.12 \mathrm{mM}$ and $0.76 \pm 0.22 \mathrm{mM}$, for control and $250 \mu \mathrm{T}$ respectively $)(\mathrm{F}(3,76)=3.6$, $p<0.05$, repeated measures ANOVA). L-Lactate concentrations in $500 \mu \mathrm{T}$ and $1000 \mu \mathrm{T}$ exposed crabs lacked a similar increase during periods of increased activity (Figure 3). Significant differences were observed in L-Lactate concentrations among treatments at different sampling times $(F(3,316)=2.92, p<0.05$, repeated measures ANOVA). Crabs exposed to $1000 \mu \mathrm{T}$ EMF showed significantly lower L-Lactate concentrations throughout the $24 \mathrm{~h}$ period $(0.24 \pm 0.07 \mathrm{mM}, p<0.05$, posthoc Tukey's test) when compared to the control values. Crabs exposed to $250 \mu \mathrm{T}$ EMF had significantly lower L-Lactate concentrations after 4 h exposure $(0.19 \pm 0.10 \mathrm{mM}, p<0.05$, posthoc Tukey's test), while $500 \mu \mathrm{T}$ exposed crabs showed significantly lower concentrations after 24 h exposure $(0.23 \pm 0.03 \mathrm{mM}, p<0.05$, posthoc Tukey's test) when compared to the control group $(0.51 \pm 0.06 \mathrm{mM})$. 


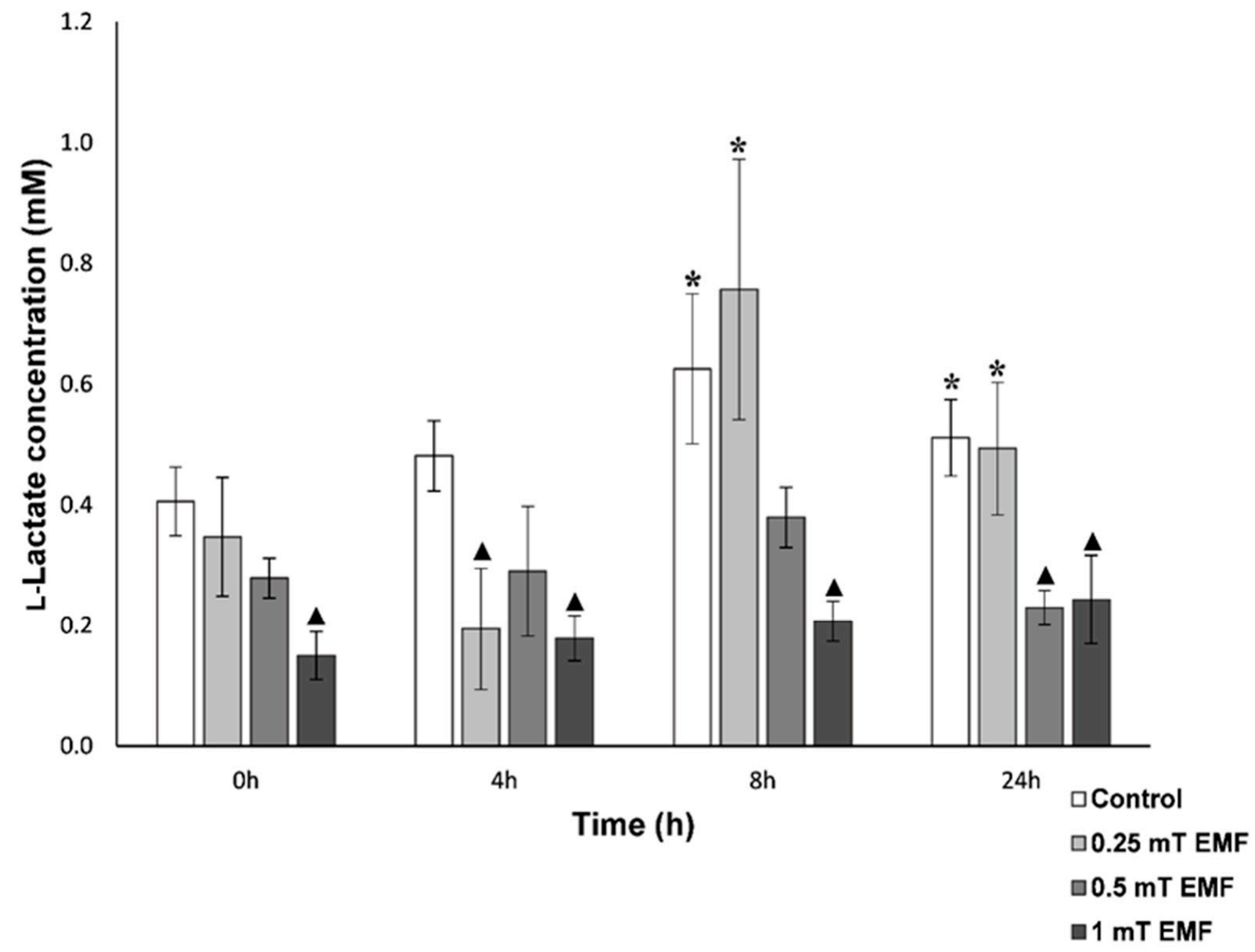

Figure 3. L-Lactate concentration over a $24 \mathrm{~h}$ period in control conditions and exposure to EMF at $250 \mu \mathrm{T}, 500 \mu \mathrm{T}, 1000 \mu \mathrm{T}$ strength. Sample times consisted of 0 h (09:00 a.m.), 4 h (13:00 p.m.), 8 h (17:00 p.m.), 24 h (09:00 a.m.). Values are presented as mean $\pm \mathrm{SEM},{ }^{*}$ is the significance from the $0 \mathrm{~h}$ within respective treatments, $\boldsymbol{\Delta}$ is the significance from the control group for each treatment at respective sampling times $\left({ }^{*}, p<0.05\right),(\boldsymbol{\Lambda}, p<0.05)$. N = 10 for control and $\mathrm{N}=10$ for EMF per treatment, total $\mathrm{N}=40$ control, $\mathrm{N}=40 \mathrm{EMF}$.

THC

Average THC in control crabs was $28.64 \pm 2.14 \times 10^{6}$ cell $\mathrm{mL}^{-1}$. Short-term rhythmical fluctuations in the control crab's THC over the $24 \mathrm{~h}$ sampling period was noted, with significantly lower values after $24 \mathrm{~h}$ (Figure 4$)(\mathrm{F}(3,156)=3.82, p<0.05$, repeated measures ANOVA). THC of crabs exposed to $250 \mu \mathrm{T}$ EMF did not differ significantly from values found in crabs kept in the control condition, with similar fluctuations during the $24 \mathrm{~h}$ period. THC of crabs exposed to $500 \mu \mathrm{T}$ and $1000 \mu \mathrm{T}$ EMF did not show similar fluctuations with no significant decrease after $24 \mathrm{~h}$ of exposure. Crabs exposed to $500 \mu \mathrm{T}$ and $1000 \mu \mathrm{T}$ showed slightly elevated values ( $38.73 \pm 6.44$ and $36.33 \pm 6.42 \times 10^{6}$ cell $\mathrm{mL}^{-1}$ respectively) after $8 \mathrm{~h}$ of exposure when compared to control values $\left(22.51 \pm 4.55 \times 10^{6} \mathrm{cell} \mathrm{mL}^{-1}\right)$ but was only statistically significant at $500 \mu \mathrm{T}$ strength ( $p<0.05$, posthoc Tukey's test). THC values after $24 \mathrm{~h}$ exposure to $500 \mu \mathrm{T}$ and $1000 \mu \mathrm{T}$ EMF returned to basal values and no statistically significant differences were found between experimental and control groups. 


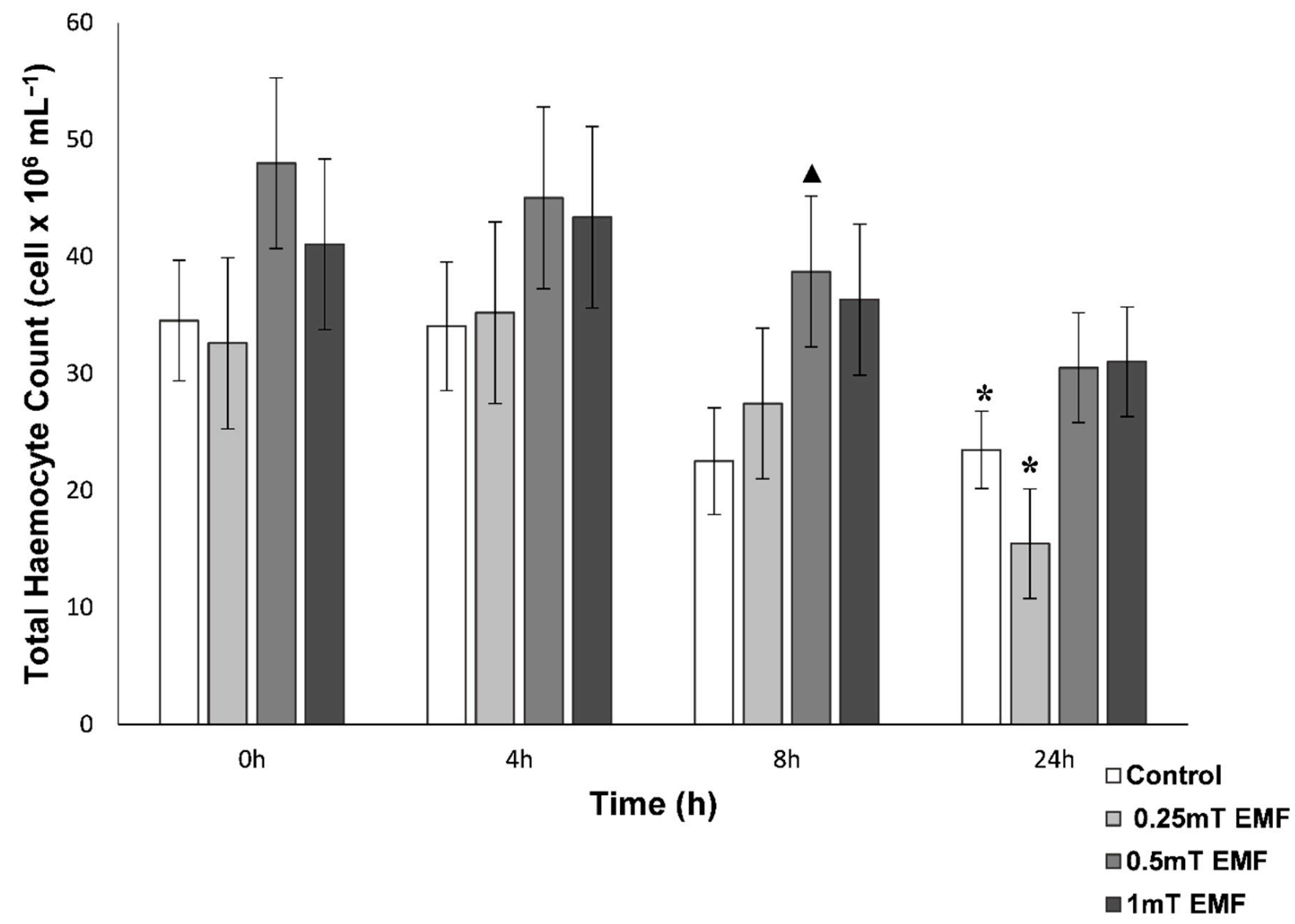

Figure 4. Total Haemocyte Count (THC) over a $24 \mathrm{~h}$ period in control conditions and constant exposure to EMF at $250 \mu \mathrm{T}$, $500 \mu \mathrm{T}, 1000 \mu \mathrm{T}$ strength. Sample times consisted of 0 h (09:00 a.m.), 4 h (13:00 p.m.), 8 h (17:00 p.m.), 24 h (09:00 a.m.). Values are presented as mean $\pm \mathrm{SEM},{ }^{*}$ is the significance from the $0 \mathrm{~h}$ within respective treatments, $\boldsymbol{\Delta}$ is the significance from the control group for each treatment at respective sampling times $\left({ }^{*}, p<0.05\right),(\boldsymbol{\Lambda}, p<0.05)$. $\mathrm{N}=10$ for control and $\mathrm{N}=10$ for EMF per treatment, total $\mathrm{N}=40$ control, $\mathrm{N}=40 \mathrm{EMF}$.

\subsection{Behavioural Analysis}

\subsubsection{Single Shelter Selection}

The mean time spent in the shelter $(256.20 \pm 36.60 \mathrm{~min})$ was slightly higher than time spent roaming the tank $(163.80 \pm 36.60 \mathrm{~min})$ in control trials (Figure 5). When there was an EMF of $250 \mu \mathrm{T}$ present, there were no significant differences between the time spent in $(273.50 \pm 14.88 \mathrm{~min})$ and out $(146.50 \pm 14.88 \mathrm{~min})$ of the shelter compared to the control. A similar pattern was observed during exposure to $500 \mu \mathrm{T}$ with no significant differences being found between time spent in $(222.63 \pm 49.14 \mathrm{~min})$ and out $(197.38 \pm 49.14 \mathrm{~min})$ of the shelter, despite a slight increase in time spent roaming the tank. Crabs spent significantly more time in the shelter $(319.63 \pm 25.73 \mathrm{~min})$ during exposure to $1000 \mu \mathrm{T}$ EMF $(\mathrm{F}(1,18)=36.3, p<0.001$, one-way ANOVA $)$. 


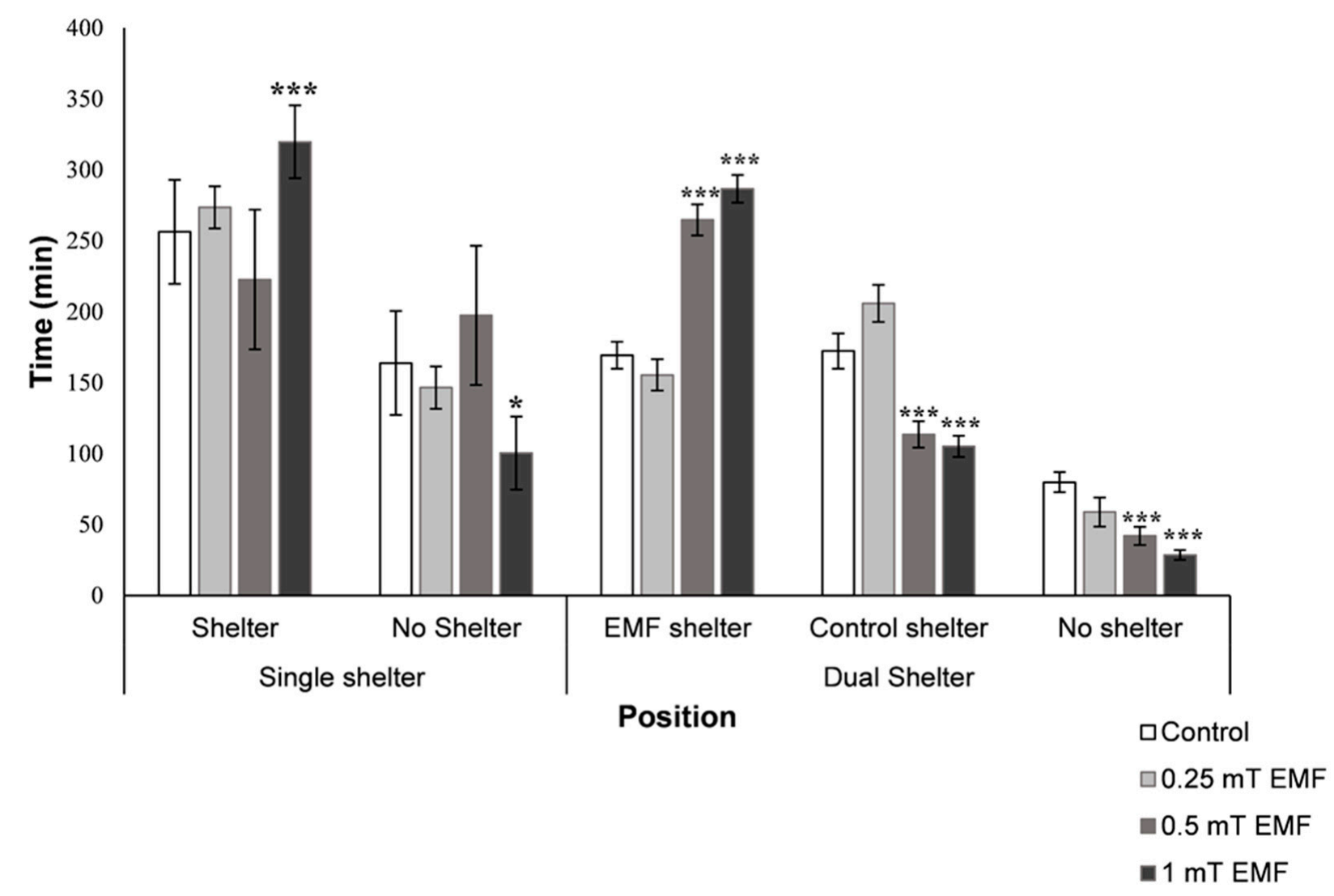

Figure 5. The effects of EMF exposure at various strengths on shelter selection in C. pagurus. Mean time spent in the shelter and roaming the tank (no shelter) in control conditions and exposure to $250 \mu \mathrm{T}, 500 \mu \mathrm{T}$, and $1000 \mu \mathrm{T}$ EMF in single shelter trials. Mean time spent within control and EMF exposed $(250 \mu \mathrm{T}, 500 \mu \mathrm{T}$, and $1000 \mu \mathrm{T}$ EMF) shelter and roaming the tank (no shelter) in dual shelter trials. Calculated as time spent in each location compared to total trial length. Values are presented as mean $\pm \mathrm{SEM},{ }^{*}$ is the significance at $p<0.05,{ }^{* * *}$ is the significance at $p<0.001$. Single shelter $\mathrm{N}_{\mathrm{CONTROL}}=10, \mathrm{~N}_{\mathrm{EMF}}=10$, dual shelter $\mathrm{N}_{\mathrm{CONTROL}}=10, \mathrm{~N}_{\mathrm{EMF}}=10$.

\subsubsection{Dual Shelter Selection}

Under control conditions, a near equal split of time was spent between the EMF shelter $(169.30 \pm 9.56 \mathrm{~min})$ and the control shelter $(172.20 \pm 12.43 \mathrm{~min})$ with $79.80 \pm 7.19 \mathrm{~min}$ time spent roaming the tank (Figure 5). Exposure to $250 \mu \mathrm{T}$ EMF did not highlight any significant changes in the time spent in shelters or roaming the tank (58.80 $\pm 10.20 \mathrm{~min}$ no shelter, $155.40 \pm 11.13$ min EMF shelter, $205.80 \pm 11.04$ min control shelter). Exposure to both $500 \mu \mathrm{T}$ and $1000 \mu \mathrm{T}$ showed significant differences compared to the control $(\mathrm{F}(3,16)=13.2, p<0.001, \mathrm{~F}(3,16)=24.3, p<0.001$, MANOVA $)$, with an increased amount of time spent within the EMF shelter $(264.60 \pm 10.96 \mathrm{~min}$, and $286.50 \pm 9.82 \mathrm{~min}$ for $500 \mu \mathrm{T}$ and $1000 \mu \mathrm{T}$ respectively). There was a drop in the mean time spent roaming the tank from $79.80 \pm 7.19 \mathrm{~min}$ in control conditions to $42.00 \pm 6.41 \mathrm{~min}$ and $28.50 \pm 3.51 \mathrm{~min}$ during exposure to $500 \mu \mathrm{T}$ and $1000 \mu \mathrm{T}$ EMF, respectively.

\section{Discussion}

It has previously been demonstrated that L-Lactate, D-Glucose and haemolymph densities are useful parameters measuring stress in crustaceans as indicators of changes in homeostasis $[36,37,42,43]$. In crustaceans, L-Lactate and D-Glucose cycle together under normal conditions. L-Lactate levels rise during periods of high locomotor activity, resulting in an increased glucose metabolism [41]. At the same time, D-Glucose levels decrease due to the increased oxidation for ATP production [44]. During the day, the reverse is observed, with a fall in L-Lactate and a subsequent rise in D-Glucose. 
At EMF exposure at $250 \mu \mathrm{T}$, L-Lactate and D-Glucose concentrations followed a natural circadian rhythm, with rises in D-Glucose throughout the day and an increase in L-Lactate in the evening corresponding with periods of higher activity. This circadian rhythm corresponds well to that found in the literature $[13,41,45]$. Values obtained for both LLactate and D-Glucose correspond to those found in previous studies [13,41,43,44,46-49]. L-Lactate concentrations observed during this study were lower than those values recorded for C. pagurus in previous work $[13,41,45]$ but still followed the same diel pattern. This variation in values could be due to the use of a different assay kit during analysis or due to the high individual variances in haemolymph L-Lactate concentrations found within this species [13]. The results obtained throughout this study suggest that exposure to $250 \mu \mathrm{T}$ EMF does not alter the circadian rhythm of L-Lactate and D-Glucose metabolism.

Exposure to EMF at $500 \mu \mathrm{T}$ and $1000 \mu \mathrm{T}$ showed the similar changes in L-Lactate levels as described previously during exposure to $2.8 \mathrm{mT}$, whereby L-Lactate concentration showed no increase during periods of higher activity [13]. The suppression of L-Lactate impacts the $\mathrm{O}_{2}$ affinity of haemocyanin, which has been shown to increase during periods of high L-Lactate concentrations to allow more oxygen to be transported around the body to counteract periods of hypoxia [50].

Exposure to $500 \mu \mathrm{T}$ and $1000 \mu \mathrm{T}$ EMF elicits the same responses in D-Glucose as has been previously described in this species during exposure to a field strength of $2.8 \mathrm{mT}$ [13]. Despite following the same circadian rhythm, D-Glucose concentrations were significantly higher after $4 \mathrm{~h}$ and $8 \mathrm{~h}$ before returning to normal levels after $24 \mathrm{~h}$. Haemolymph D-Glucose and L-Lactate should cycle together in normal unstressed conditions but have been shown to be affected by certain environmental stressors $[13,48,51,52]$. D-Glucose has a negative correlation with vigour, with moribund crabs becoming hyperglycaemic [38]. Evidence suggests that D-Glucose and L-Lactate cycles are controlled by melatonin, a neuropeptide present in crustaceans [49]. Earlier studies have suggested that EMF exposure impacts melatonin levels by decreasing melatonin synthesis [53-55]. This study adds more evidence to this hypothesis by finding similar circadian disruption in D-Glucose and L-Lactate at $500 \mu \mathrm{T}$ and $1000 \mu \mathrm{T}$ EMF exposure.

The THC values obtained throughout this study correspond well with those previously recorded for C. pagurus in the literature. Vogan and Rowley recorded values of $2.55 \pm 0.14 \times 10^{7}$ cell $\mathrm{mL}^{-1}$ [56], Lorenzon et al. found values of $3.19 \pm 0.92 \times 10^{7}$ cell $\mathrm{mL}^{-1}$ [38], and more recently Parrinello et al. observed values of $4.4 \pm 0.6 \times 10^{7}$ cell mL ${ }^{-1}$ [57]. In shore crab, Carcinus maenas (Linnaeus, 1758), a study conducted in North Wales by Truscott and White found significant differences in THC concentrations between high and low tides with double the concentration recorded at $8 \mathrm{~m}$ compared to a $4 \mathrm{~m}$ tide [58]. This suggests that there may be natural variations in THC in C. pagurus which may explain some of the changes detected during experimentation.

In previous work [45], THC in the European lobster (Homarus Gammarus, Linnaeus, 1758) was significantly affected by exposure to an EMF of $2.8 \mathrm{mT}$ resulting in lower mean values after $12 \mathrm{~h}$ with significant increases between $6 \mathrm{~h}$ and $24 \mathrm{~h}$. However, in this study, a significant rise after $8 \mathrm{~h}$ was detected during exposure to $500 \mu \mathrm{T}$ EMF. During exposure to control and $250 \mu \mathrm{T}$, there were significant drops in THC after $24 \mathrm{~h}$, whilst no significant decreases were detected in $500 \mu \mathrm{T}$ and $1000 \mu \mathrm{T}$. Large variations in THC concentration were found in individuals throughout this study which may have masked some of the effects of the treatment. Previous studies have shown that THC levels rise during exposure to increased stress suggesting an immune response $[59,60]$. However, the reverse has also been confirmed with a decrease in THC resulting from the presence of stressors including bacteria [61], hypoxia [62] and EMF [63]. Significant variations from the normal rhythmic patterns of THC were detected during exposure to $500 \mu \mathrm{T}$ and $1000 \mu \mathrm{T}$ suggesting the beginning of an immune response. Exposure to $250 \mu \mathrm{T}$ showed no significant differences from the control suggesting EMF at these strengths may not result in reduced immune capacity. 
During single shelter trials, a higher percentage of time was spent within the shelter than roaming the tank (across all treatments), although this was lower than the results obtained for C. pagurus in previous work [13]. This conforms to previous findings that crustaceans show high utilisation of shelters with periods of time spent roaming out with $[13,64]$. No significant changes were noted when the shelter was subjected to an EMF of $250 \mu \mathrm{T}$. This result, combined with those obtained from the physiological analysis, suggests that EMF exposure of $250 \mu \mathrm{T}$ does not negatively impact C. pagurus on a behavioural or physiological level, via tested parameters, as previously found with higher strengths [13]. During exposure to $500 \mu \mathrm{T}$ EMF, a slight decrease in time spent in the shelter occurred, which also occurred with H. gammarus [45]. At $1000 \mu \mathrm{T}$ there was a clear attraction to the source of the EMF with a significant increase in time spent within the EMF exposed shelter. Results obtained from the dual shelter trials confirm an apparent lack of response during exposure to $250 \mu \mathrm{T}$. The remaining dual shelter EMF strengths highlighted an attraction to the EMF source with significant increases in the time spent within the shelter and decreased time roaming the tank.

This increased attraction to the source of the EMF, despite showing signs of physiological stress, has clear implications for C. pagurus in areas around MREDs. Many offshore sites have introduced no-take zones around turbine arrays, with speculation that the decrease in fishing pressure, combined with the addition of artificial reefs in the form of scour protection blocks, could enhance the overall crustacean population by providing refuge and breeding areas [27]. However, an attraction to subsea power cables emitting an EMF of $>500 \mu \mathrm{T}$ could come at the cost of time spent foraging for food, seeking mates, and potentially finding shelter, which is a cause for concern. Although the primary underlying mechanism responsible for the effects of EMF on living organisms is unclear changes in cell membrane permeability, gene and protein expression, and developmental changes such as cell growth and proliferation have all been documented during exposure to EMF [65-67]. The impacts of increased EMF exposure can be determined on a number of individuals but determining the impacts on a population level is considerably more difficult. The key link in determining population wide impacts is the development and recruitment of juveniles into the ecological system. The impacts of EMF exposure on brooding females and the subsequent impact on the larvae are currently unknown and needs to be addressed to accurately determine population level impacts. With the addition of scour protection zones aiming to increase biodiversity [26,28], and the plan to co-locate aquaculture around windfarm sites $[4,68]$, there is a clear need to consider the impacts of EMF emissions on benthic species around these sites.

The data presented in this paper can be meaningfully considered alongside previous studies on this species by Scott et al. (Table 1) [13]. 
Table 1. Summary of the impacts of C. pagurus during exposure to multiple EMF strengths from the current study and Scott et al. [13].

\begin{tabular}{|c|c|c|c|c|c|}
\hline \multirow{2}{*}{ EMF Levels } & \multicolumn{3}{|c|}{ Physiological Analyses } & \multicolumn{2}{|c|}{ Behavioural Analyses } \\
\hline & L-Lactate Changes & D-Glucose Changes & THC & Single Shelter Selection & Dual Shelter Selection \\
\hline $250 \mu \mathrm{T}$ & $\begin{array}{c}\text { Followed circadian rhythm, } \\
\text { but lower concentrations after } \\
44 \mathrm{~h}\end{array}$ & $\begin{array}{l}\text { No significant difference to } \\
\text { control }\end{array}$ & $\begin{array}{c}\text { No significant difference to } \\
\text { control }\end{array}$ & $\begin{array}{l}\text { No significant difference in } \\
\text { time spent inside shelter or } \\
\text { roaming compared to control }\end{array}$ & $\begin{array}{l}\text { No significant difference in } \\
\text { time spent in either shelter or } \\
\text { roaming compared to control }\end{array}$ \\
\hline $500 \mu \mathrm{T}$ & $\begin{array}{c}\text { Did not follow circadian } \\
\text { rhythm, lower concentrations } \\
\text { after } 24 \mathrm{~h}\end{array}$ & $\begin{array}{l}\text { Followed circadian rhythm, } \\
\text { but hyperglycaemia seen } \\
\text { after } 4 \mathrm{~h} \text { and } 8 \mathrm{~h}\end{array}$ & $\begin{array}{c}\text { No fluctuations in levels nor } \\
\text { significant decrease after } 24 \mathrm{~h} \\
\text { (as seen in control), elevated } \\
\text { levels after } 8 \mathrm{~h}\end{array}$ & $\begin{array}{l}\text { No significant difference in } \\
\text { time spent inside shelter or } \\
\text { roaming compared to control }\end{array}$ & $\begin{array}{l}\text { Increased time in EMF shelter } \\
\text { and reduced time roaming }\end{array}$ \\
\hline $1000 \mu \mathrm{T}$ & $\begin{array}{l}\text { Did not follow circadian } \\
\text { rhythm, lower concentrations } \\
\text { throughout } 24 \mathrm{~h} \text { period }\end{array}$ & $\begin{array}{c}\text { Followed circadian rhythm, } \\
\text { but hyperglycaemia seen } \\
\text { after } 4 \mathrm{~h} \text { and } 8 \mathrm{~h}\end{array}$ & $\begin{array}{l}\text { No fluctuations in levels nor } \\
\text { significant decrease after } 24 \mathrm{~h} \\
\text { (as seen in control) }\end{array}$ & $\begin{array}{l}\text { Significantly more time spent } \\
\text { in the shelter }\end{array}$ & $\begin{array}{l}\text { Increased time in EMF shelter } \\
\text { and reduced time roaming }\end{array}$ \\
\hline $2.8 \mathrm{mT}$ & $\begin{array}{l}\text { Did not follow circadian } \\
\text { rhythm, lower concentrations } \\
\text { throughout } 24 \text { h period } \\
\text { (without usual peaks at } \\
\text { dawn) }\end{array}$ & $\begin{array}{l}\text { Followed circadian rhythm, } \\
\text { but did not show significant } \\
\text { rise in levels after } 8 \mathrm{~h} \text {, as seen } \\
\text { in control }\end{array}$ & Not assessed & $\begin{array}{c}\text { Significantly more time spent } \\
\text { in the shelter and reduced } \\
\text { roaming }\end{array}$ & $\begin{array}{l}\text { Increased time in EMF shelter } \\
\text { and reduced time roaming }\end{array}$ \\
\hline
\end{tabular}




\section{Conclusions}

The results obtained from this study, combined with the data from previous work [13,41], suggests that increased physiological stress will occur if $C$. pagurus is exposed to EMF of $500 \mu \mathrm{T}$ or above with data obtained at $1000 \mu \mathrm{T}, 2.8 \mathrm{mT}$ and $40 \mathrm{mT}$ confirming this trend. This is mirrored in the behavioural trends noted, which showed an attraction to EMF sources at the same levels despite the physiological ramifications.

This suggests that a working limit of a maximum of $250 \mu \mathrm{T}$ could result in minimal physiological and behavioural changes within this species and should be considered during MRED design and implementation. Additional research is required to further identify sensitivities to EMF in different life stages and conditions within this species and benthic crustaceans in general.

Author Contributions: Conceptualisation, K.S., P.H., A.R.L.; methodology, K.S. and P.H.; validation, K.S. and P.H.; formal analysis, P.H.; investigation, K.S., P.H., B.A.A.E., A.J.R.P., C.M.V.R.; resources, K.S., P.H., B.A.A.E.; data curation, P.H., B.A.A.E., A.J.R.P., C.M.V.R.; writing-original draft preparation, K.S.; writing—review and editing, K.S., P.H., B.A.A.E., A.J.R.P., C.M.V.R.; visualisation, P.H. and A.J.R.P.; supervision, A.R.L.; project administration, K.S.; funding acquisition, K.S. All authors have read and agreed to the published version of the manuscript.

Funding: This research was funded by the Nesbitt-Cleland Trust. Previous funding obtained from the Scottish Fishermen's Federation aided this research. Consumables were funded through St Abbs Marine Station.

Institutional Review Board Statement: Formal ethical review and approval were waived for this study, due to this species not being listed under Animals (Scientific Procedures) Act 1986 (ASPA). Animal collection was conducted with the local commercial fishing fleet and did not require collection permits. Informal ethic review and approval was conducted by authors and trustees of St Abbs Marine Station using published literature and information obtained from Animals (Scientific Procedures) Act 1986 (ASPA).

Informed Consent Statement: Not applicable.

Data Availability Statement: Data presented in this article are available on request from the corresponding author.

Acknowledgments: The help of both past and present marine station volunteers are greatly acknowledged.

Conflicts of Interest: The authors declare no conflict of interest. The funders had no role in the design of the study; in the collection, analyses, or interpretation of data; in the writing of the manuscript, or in the decision to publish the results.

\section{References}

1. Inger, R.; Attrill, M.J.; Bearhop, S.; Broderick, A.C.; Grecian, J.W.; Hodgson, D.J.; Mills, C.; Sheehan, E.; Votier, S.C.; Witt, M.J. Marine renewable energy: Potential benefits to biodiversity? An urgent call for research. J. Appl. Ecol. 2009, 46, 1145-1153. [CrossRef]

2. Boehlert, G.W.; Gill, A.B. Environmental and ecological effects of ocean renewable energy development: A current synthesis. Oceanography 2010, 23, 68-81. [CrossRef]

3. Dannheim, J.; Bergström, L.; Birchenough, S.N.; Brzana, R.; Boon, A.R.; Coolen, J.W.; Dauvin, J.-C.; De Mesel, I.; Derweduwen, J.; Gill, A.B. Benthic effects of offshore renewables: Identification of knowledge gaps and urgently needed research. ICES J. Mar. Sci. 2020, 77, 1092-1108. [CrossRef]

4. Causon, P.D.; Gill, A.B. Linking ecosystem services with epibenthic biodiversity change following installation of offshore wind farms. Environ. Sci. Policy 2018, 89, 340-347. [CrossRef]

5. Fichaux, N.; Wilkes, J.; Van Hulle, F.; Cronin, A. Oceans of Opportunity: Harnessing Europe's Largest Domestic Energy Resource; European Wind Energy Association: Brussels, Belgium, 2009. Available online: http:/ /www.ewea.org/fileadmin/files/library/ publications/reports/Offshore_Report_2009.pdf (accessed on 16 July 2021).

6. Komusanac, I.; Fraile, D.; Brindley, G. Wind energy in Europe in 2018-Trends and statistics. Wind Eur. 2019, 9-10. Available online: https:/ / windeurope.org/about-wind/statistics/european/wind-energy-in-europe-in-2018/ (accessed on 16 July 2021).

7. Fraile, D.M.A. Wind in Power: 2016 European Statistics; Wind Europe: Brussels, Belgium, 2017. 
8. TCE. The Crown Estate from Every Perspective; The Corwn Estate: London, UK, 2017. Available online: https://assets.publishing. service.gov.uk/government/uploads/system/uploads/attachment_data/file/622107/TCE_accounts_16-17.pdf (accessed on 16 July 2021).

9. Pelc, R.; Fujita, R.M. Renewable energy from the ocean. Mar. Policy 2002, 26, 471-479. [CrossRef]

10. Gill, A.B. Offshore renewable energy: Ecological implications of generating electricity in the coastal zone. J. Appl. Ecol. 2005, 42, 605-615. [CrossRef]

11. Cada, G.; Ahlgrimm, J.; Bahleda, M.; Bigford, T.; Stavrakas, S.D.; Hall, D.; Moursund, R.; Sale, M. Potential impacts of hydrokinetic and wave energy conversion technologies on aquatic environments. Fisheries 2007, 32, 174-181. [CrossRef]

12. Boehlert, G.W.; McMurray, G.R.; Tortorici, C.E. Ecological Effects of Wave Energy Development in the Pacific Northwest: A Scientific Workshop, October 11-12, 2007; NOAA: Silver Spring, MD, USA, 2008. Available online: https:/ /nmsfarallones.blob.core.windows. net/farallones-prod/media/archive/manage/pdf/sac/13_02_workshop/wave_energy.pdf (accessed on 16 July 2021).

13. Scott, K.; Harsanyi, P.; Lyndon, A.R. Understanding the effects of electromagnetic field emissions from Marine Renewable Energy Devices (MREDs) on the commercially important edible crab, Cancer pagurus (L.). Mar. Pollut. Bull. 2018, 131, 580-588. [CrossRef]

14. De Luca, R. Lorentz force on sodium and chlorine ions in a salt water solution flow under a transverse magnetic field. Eur. J. Phys. 2009, 30, 459. [CrossRef]

15. Tricas, T.C. Effects of Emfs from Undersea Power Cables on Elasmobranchs and Other Marine Species; DIANE Publishing: Darby, PA, USA, 2012

16. Thomsen, F.; Gill, A.; Kosecka, M.; Andersson, M.; Andre, M.; Degraer, S.; Folegot, T.; Gabriel, J.; Judd, A.; Neumann, T. MarvenEnvironmental Impacts of Noise, Vibrations and Electromagnetic Emissions From Marine Renewable Energy; Final Study Report; DG RTD (Directorate-General for Research and Innovation of the European Commission): Brussels, Belgium, 2015. Available online: https: / / tethys.pnnl.gov / publications / marven-environmental-impacts-noise-vibrations-electromagnetic-emissions-marine (accessed on 16 July 2021).

17. Bochert, R.; Zettler, M.L. Effect of electromagnetic fields on marine organisms. In Offshore Wind Energy; Springer: Berlin/Heidelberg, Germany, 2006; pp. 223-234.

18. Cada, G.F.; Bevelhimer, M.S.; Riemer, K.P.; Turner, J.W. Effects on Freshwater Organisms of Magnetic Fields Associated with Hydrokinetic Turbines; ORNL/TM-2011/244; Oak Ridge National Laboratory: Oak Ridge, TN, USA, 2011.

19. Brewer, H. Some preliminary studies of the effects of a static magnetic field on the life cycle of the Lebistes reticulatus (Guppy). Biophys. J. 1979, 28, 305-314. [CrossRef]

20. Formicki, K.; Sadowski, M.; Tański, A.; Korzelecka-Orkisz, A.; Winnicki, A. Behaviour of trout (Salmo trutta L.) larvae and fry in a constant magnetic field. J. Appl. Ichthyol. 2004, 20, 290-294. [CrossRef]

21. Bochert, R.; Zettler, M. Long-term exposure of several marine benthic animals to static magnetic fields. J. Bioelectromagn. Soc. 2004, 25, 498-502. [CrossRef] [PubMed]

22. Woodruff, D.L.; Schultz, I.R.; Marshall, K.E.; Ward, J.A.; Cullinan, V.I. Effects of Electromagnetic Fields on Fish and Invertebrates: Task 2.1.3: Effects on Aquatic Organisms-Fiscal Year 2011 Progress Report-Environmental Effects of Marine and Hydrokinetic Energy; Progress Report; Pacific Northwest National Lab. (PNNL): Richland, WA, USA, 2012.

23. Bakke, S.; Buhl-Mortensen, L.; Buhl-Mortensen, P. Some observations of Cancer pagurus Linnaeus, 1758 (Decapoda, Brachyura) in deep water. Crustaceana 2019, 92, 95-105. [CrossRef]

24. Statistics, N. UK Sea Fisheries Statistics 2019; MMO: Newcastle, UK, 2019. Available online: https:/ / thefishingdaily.com/latestnews / mmo-releases-uk-sea-fisheries-annual-statistics-report-2019/ (accessed on 16 July 2021).

25. Landers, D.F., Jr.; Keser, M.; Saila, S.B. Changes in female lobster (Homarus americanus) size at maturity and implications for the lobster resource in Long Island Sound, Connecticut. Mar. Freshw. Res. 2001, 52, 1283-1290. [CrossRef]

26. Kawasaki, H.; Sano, M.; Shibuno, T. The relationship between habitat physical complexity and recruitment of the coral reef damselfish, Pomacentrus amboinensis: An experimental study using small-scale artificial reefs. Ichthyol. Res. 2003, 50, 0073-0077. [CrossRef]

27. Langhamer, O.; Wilhelmsson, D. Colonisation of fish and crabs of wave energy foundations and the effects of manufactured holes-a field experiment. Mar. Environ. Res. 2009, 68, 151-157. [CrossRef]

28. Burdon, D. Offshore and Coastal Renewable Energy: Potential Ecological Benefits and Impacts of Large-Scale Offshore and Coastal Renewable Energy; Final Report, Tethys; 2009. Available online: https:/ / tethys.pnnl.gov/publications/offshore-coastal-renewable-energypotential-ecological-benefits-impacts-large-scale (accessed on 16 July 2021).

29. Lindeboom, H.; Kouwenhoven, H.; Bergman, M.; Bouma, S.; Brasseur, S.; Daan, R.; Fijn, R.; De Haan, D.; Dirksen, S.; Van Hal, R. Short-term ecological effects of an offshore wind farm in the Dutch coastal zone; a compilation. Environ. Res. Lett. $2011,6,035101$. [CrossRef]

30. Walker, M.M.; Diebel, C.E.; Haugh, C.V.; Pankhurst, P.M.; Montgomery, J.C.; Green, C.R. Structure and function of the vertebrate magnetic sense. Nature 1997, 390, 371-376. [CrossRef]

31. Ernst, D.A.; Lohmann, K.J. Effect of magnetic pulses on Caribbean spiny lobsters: Implications for magnetoreception. J. Exp. Biol. 2016, 219, 1827-1832. [CrossRef]

32. Kirschvink, J.L.; Walker, M.M.; Diebel, C.E. Magnetite-based magnetoreception. Curr. Opin. Neurobiol. 2001, 11, 462-467. [CrossRef] 
33. Walker, M.M. A model for encoding of magnetic field intensity by magnetite-based magnetoreceptor cells. J. Theor. Biol. 2008, 250, 85-91. [CrossRef] [PubMed]

34. Lohmann, K.J. Magnetic remanence in the western Atlantic spiny lobster, Panulirus argus. J. Exp. Biol. 1984, 113, 29-41. [CrossRef]

35. Paterson, B.D.; Spanoghe, P.T. Stress indicators in marine decapod crustaceans, with particular reference to the grading of western rock lobsters (Panulirus cygnus) during commercial handling. Mar. Freshw. Res. 1997, 48, 829-834. [CrossRef]

36. Taylor, H.; Paterson, B.; Wong, R.; Wells, R. Physiology and live transport of lobsters: Report from a workshop. Mar. Freshw. Res. 1997, 48, 817-822. [CrossRef]

37. Bergmann, M.; Taylor, A.C.; Moore, P.G. Physiological stress in decapod crustaceans (Munida rugosa and Liocarcinus depurator) discarded in the Clyde Nephrops fishery. J. Exp. Mar. Biol. Ecol. 2001, 259, 215-229. [CrossRef]

38. Lorenzon, S.; Giulianini, P.G.; Libralato, S.; Martinis, M.; Ferrero, E. Stress effect of two different transport systems on the physiological profiles of the crab Cancer pagurus. Aquaculture 2008, 278, 156-163. [CrossRef]

39. Hutchison, Z.; Sigray, P.; He, H.; Gill, A.; King, J.; Gibson, C. Electromagnetic Field (EMF) impacts on elasmobranch (shark, rays, and skates) and American lobster movement and migration from direct current cables. OCS Study BOEM 2018, 1-3. Available online: https:/ / tethys.pnnl.gov / publications/electromagnetic-field-emf-impacts-elasmobranch-shark-rays-skates-americanlobster (accessed on 16 July 2021).

40. Moray Offshore Renewables. Telford, Stevenson, MacColl Wind Farms and associated Transmission Infrastructure Environmental Statement-Technical Appendix 4.3 D-Electromagnetic Fields Modelling. 2019. Available online: https://www.morayeast.com/ application/files/1515/8014/0011/Appendix-1-3-E-Preliminary-Decommissioning-Programme.pdf (accessed on 16 July 2021).

41. Scott, K.; Harsanyi, P.; Lyndon, A.R. Baseline measurements of physiological and behavioural stress markers in the commercially important decapod Cancer pagurus (L.). J. Exp. Mar. Biol. Ecol. 2018, 507, 1-7. [CrossRef]

42. Durand, F.; Devillers, N.; Lallier, F.H.; Regnault, M. Nitrogen excretion and changes in blood components during emersion of the subtidal spider crab Maia squinado (L.). Comp. Biochem. Physiol. Part A Mol. Integr. Physiol. 2000, 127, 259-271. [CrossRef]

43. Lorenzon, S.; Martinis, M.; Ferrero, E.A. Ecological relevance of hemolymph total protein concentration in seven unrelated crustacean species from different habitats measured predictively by a density-salinity refractometer. J. Mar. Biol. 2011, $2011,1-7$. Available online: https://www.hindawi.com/journals/jmb/2011/153654/ (accessed on 16 July 2021). [CrossRef]

44. Barrento, S.; Marques, A.; Vaz-Pires, P.; Nunes, M.L. Live shipment of immersed crabs Cancer pagurus from England to Portugal and recovery in stocking tanks: Stress parameter characterization. ICES J. Mar. Sci. 2010, 67, 435-443. [CrossRef]

45. Scott, K. Understanding the Biology of Two Commercially Important Crustaceans in Relation to Fisheries and Anthropogenic Impacts. Ph.D. Thesis, Heriot-Watt University, Edinburgh, UK, 2019. Available online: https://www.ros.hw.ac.uk/handle/1039 9/4184 (accessed on 16 July 2021).

46. Watt, A.; Whiteley, N.; Taylor, E. An in situ study of respiratory variables in three British sublittoral crabs with different routine rates of activity. J. Exp. Mar. Biol. Ecol. 1999, 239, 1-21. [CrossRef]

47. Reddy, D.; Raghupathi, M.; Purushotham, K.; Naidu, B. Daily rhythms in levels of blood glucose and hepatopancreatic glycogen in the fresh water field crab Oziotelphusa senex senex (Fabricius). Indian J. Exp. Biol. 1981, 4, 403-404. Available online: https: / / pubmed.ncbi.nlm.nih.gov/7275199/ (accessed on 16 July 2021).

48. Kallen, J.L.; Abrahamse, S.; Van Herp, F. Circadian rhythmicity of the crustacean hyperglycemic hormone (CHH) in the hemolymph of the crayfish. Biol. Bull. 1990, 179, 351-357. [CrossRef]

49. Tilden, A.; McGann, L.; Schwartz, J.; Bowe, A.; Salazar, C. Effect of melatonin on hemolymph glucose and lactate levels in the fiddler crab Uca pugilator. J. Exp. Zool. 2001, 290, 379-383. [CrossRef] [PubMed]

50. Sanders, N.; Childress, J. Specific effects of thiosulphate and L-lactate on hemocyanin- $\mathrm{O}_{2}$ affinity in a brachyuran hydrothermal vent crab. Mar. Biol. 1992, 113, 175-180. [CrossRef]

51. Reddy, P.; Katyayani, R.; Fingerman, M. Cadmium and naphthalene-induced hyperglycemia in the fiddler crab, Uca pugilator: Differential modes of action on the neutroendocrine system. Bull. Environ. Contam. Toxicol. 1996, 56, 425-431. Available online: https: / / pubmed.ncbi.nlm.nih.gov/8825965/ (accessed on 16 July 2021). [CrossRef] [PubMed]

52. Chang, E.S.; Keller, R.; Chang, S.A. Quantification of crustacean hyperglycemic hormone by ELISA in hemolymph of the lobster, Homarus americanus, following various stresses. Gen. Comp. Endocrinol. 1998, 111, 359-366. [CrossRef]

53. Reiter, R.J. Static and extremely low frequency electromagnetic field exposure: Reported effects on the circadian production of melatonin. J. Cell. Biochem. 1993, 51, 394-403. [CrossRef]

54. Schneider, T.; Thalau, H.-P.; Semm, P. Effects of light or different earth-strength magnetic fields on the nocturnal melatonin concentration in a migratory bird. Neurosci. Lett. 1994, 168, 73-75. [CrossRef]

55. Wood, A.; Sait, M.; Armstrong, S.; Martin, M. Effects of $50 \mathrm{~Hz}$ magnetic fields on human physiology: Plasma melatonin levels. In Proceedings of the 2nd International Conference on Bioelectromagnetism (Cat. No. 98TH8269), Melbourne, Australia, 15-18 February 1998; pp. 161-162.

56. Vogan, C.L.; Rowley, A.F. Effects of shell disease syndrome on the haemocytes and humoral defences of the edible crab, Cancer pagurus. Aquaculture 2002, 205, 237-252. [CrossRef]

57. Parrinello, D.; Sanfratello, M.; Celi, M.; Vazzana, M. Hemocyte types and some plasmatic properties of two edible crabs Cancer borealis and Cancer pagurus. Invertebr. Surviv. J. 2015, 12, 195-202.

58. Truscott, R.; White, K. The influence of metal and temperature stress on the immune system of crabs. Funct. Ecol. 1990, 4, 455-461. Available online: https:/ / www.jstor.org/stable/2389609 (accessed on 16 July 2021). [CrossRef] 
59. Le Moullac, G.; Haffner, P. Environmental factors affecting immune responses in Crustacea. Aquaculture 2000, 191, 121-131. [CrossRef]

60. Monari, M.; Matozzo, V.; Foschi, J.; Cattani, O.; Serrazanetti, G.P.; Marin, M.G. Effects of high temperatures on functional responses of haemocytes in the clam Chamelea gallina. Fish. Shellfish Immunol. 2007, 22, 98-114. [CrossRef]

61. Stewart, J.E.; Cornick, J.W.; Dingle, J. An electronic method for counting lobster (Homarus americanus Milne Edwards) hemocytes and the influence of diet on hemocyte numbers and hemolymph proteins. Can. J. Zool. 1967, 45, 291-304. [CrossRef]

62. Le Moullac, G.; Soyez, C.; Saulnier, D.; Ansquer, D.; Avarre, J.C.; Levy, P. Effect of hypoxic stress on the immune response and the resistance to vibriosis of the shrimpPenaeus stylirostris. Fish. Shellfish Immunol. 1998, 8, 621-629. [CrossRef]

63. Valadez-Lira, J.A.; Medina-Chavez, N.O.; Orozco-Flores, A.A.; Heredia-Rojas, J.A.; Rodriguez-de la Fuente, A.O.; Gomez-Flores, R.; Alcocer-Gonzalez, J.M.; Tamez-Guerra, P. Alterations of immune parameters on Trichoplusia ni (Lepidoptera: Noctuidae) larvae exposed to extremely low-frequency electromagnetic fields. Environ. Entomol. 2017, 46, 376-382. [CrossRef]

64. Skajaa, K.; Fernö, A.; Løkkeborg, S.; Haugland, E.K. Basic movement pattern and chemo-oriented search towards baited pots in edible crab (Cancer pagurus L.). Hydrobiologia 1998, 371, 143-153. [CrossRef]

65. Kawakami, S.; Kashiwagi, K.; Furuno, N.; Yamashita, M.; Kashiwagi, A.; Tanimoto, Y. Effects of strong static magnetic fields on amphibian development and gene expression. Jpn. J. Appl. Phys. 2006, 45, 6055. [CrossRef]

66. Sakhnini, L.; Dairi, M. Effects of static magnetic fields on early embryonic development of the sea urchin Echinometra mathaei. IEEE Trans. Magn. 2004, 40, 2979-2981. [CrossRef]

67. Petrov, E.; Martinac, B. Modulation of channel activity and gadolinium block of MscL by static magnetic fields. Eur. Biophys. J. 2007, 36, 95. [CrossRef] [PubMed]

68. Holm, P.; Buck, B.H.; Langan, R. Introduction: New approaches to sustainable offshore food production and the development of offshore platforms. In Aquaculture Perspective of Multi-Use Sites in the Open Ocean; Springer: Berlin/Heidelberg, Germany, 2017; pp. 1-20. 